at M.I.T.

Dr. Amemiya is continuing his Post-Doctoral Fellowship, working with Professor Halperin.

University of Western Ontario: The following are additions to the staff of the Department of Mathematics and Astronomy: Dr. Harvey Arnold (Assistant Professor), Dr. W.A. O'N. Waugh (Assistant Professor).

The name of the Department has been altered to "Department of Pure and Applied Mathematics and Astronomy". By tine end of the current academic year the Department will be offer ing separate major programs in Statistics, Actuarial Mathematics, Pure Mathematics, Applied Mathematics, and Astronomy.

\title{
RESUMES DE THESES DE DOCTORAT
}

Olgierd BIBERSTEIN, Géométrie differentielle Minkowskienne, thè se présentée à $1^{\prime}$ Université de Montréal, septembre 1957 (professeur I. Fary, directeur)

La première partie de ce travail est consacrée à la géométrie différentielle du plan de Minkowski. On introduit une famille de repères affines dits "minkowskiens" analogues aux repères orthonormés dans le plan euclidien. Le "repère de Frenet" d'une courbe est un repère minkowskien convenable; on démontre des "formules de Frenet" qui, outre une courbure $k$ définie autrement par M. Busemann, mettent en jeu l'invariant $\bar{K}=K \lambda^{-1}$ dit "anti-courbure", $\lambda$ désignant la courbure de "l'isopérimétrice" du même auteur. La considération des repères minkowskiens et de l'anti-courbure éclaircit le role important (resté peut-être un peu mystérieux jusqu'ici) joué en géométrie minkowskienne par l'isopérimétrice. Les théorèmes les plus connus de la géomètrie différentielle du plan euclidien se généralisent facilement; en outre un théoréme euclidien apparaît le plus souvent comme spécialisant deux théorèmes minkowskiens distincts.

Dans la deuxième partie consacrée à la géométrie minkowskienne à trois dimensions intervient, à titre fondamental, une "première transformation de courbure" dont le déterminant est la "courbure gaussienne" (autre que celle de M. Busemann) de la surface. Les "déplacements infinitésimaux" d'un repère dit "semi-minkowskien" et d'un repère dit "minkowskien" sont car- 
actérisés à l'aide des "matrices de courbure" de l'indicatrice et de l'isopérimétrice; les formules y afférentes constituent notre outil principal. Une forme quadratique $F_{2}$ analogue à la deuxième forme quadratique euclidienne se définit au moyen de la transformation de courbure. Une "deuxième transformation de courbure" déjà étudiée par MM. Duschek et Busemann se trouve éclairée d'un jour nouveau par le fait qu'elle est rattachée aux "premières" transformations de courbure de la surface et de l'isopérimétrice. Les résultats des auteurs mentionnés relatifs à une "courbure normale" (que du reste ils ne nomment pas) sont retrouvés et complétés par une étude parallèle d'une "torsion relative". On démontre à l'aide d'équations "de structure" une propriété caractéristique "extrinsèque" des géodésiques d'une surface. Des formules "de Frenet" et du type "de BonnetKowalewski" sont établies pour une courbe gauche et une courbe tracée sur une surface. Deux théorèmes, l'un ayant rapport à l'axe de courbure, l'autre au plan rectifiant d'une courbe gauche exploitent une "orthogonalité" engendrée par la forme $F_{2}$ de l'indicatrice. Enfin on propose une différentiation absolue nonlinéaire qui permet de vérifier le caractère intrinsèque d'une courbure géodésique antérieurement définie.

George E. CROSS, On the Uniqueness of Multiple Trigonometric Series, presented at U.B.C., September 1958 (Supervisor, Professor R. D. James).

The multiple trigonometric series $\sum c_{m} \exp (i(m, x))$, where $m=\left(m_{1}, \ldots, m_{n}\right), x=\left(x_{1}, \ldots, x_{n}\right),(m, x)=m_{1} x_{1}+\ldots+m_{n} x_{n}$, and $m_{i} \geqslant 0$ is said to be summable $(T, k)$ if the series $\sum C_{p}(x)$ is summable $(C, k)$, where $C_{p}(x)$ denotes the triangular sum $\sum c_{m} \exp (i(m, x)), m_{1}+\ldots+m_{n}=p$. The series is said to be bounded $(T, k)$ if the series $\sum C_{p}(x)$ is bounded $(C, k)$.

Using the fact that the triangular summation of multiple trigonometric series considered is equivalent to the Cesaro summation of a single series of a particular form, this thesis obtains uniqueness theorems for multiple trigonometric series by first proving the required theorems for the single series.

It is shown that if the series $\sum c_{n} \exp (i n t)$ is summable $(C, k)$ then the coefficients $c_{n}$ are given in terms of the $p^{k+2}$ integral defined by James [Trans. Amer. Math. Soc. 76 (1954), 149-176, Section 8]. When the series is bounded $(C, k)$ a Fourier representation is obtained in terms of Burkill's $\mathrm{C}_{k+1} \mathrm{P}$-integral 
[Proc. London Math. Soc. (2) 39 (1935), 541-552].

It is shown that if $f(t)$ is periodic and $C_{r} P$-integrable, then the definite $C_{r} P$-integral is a constant multiple of the definite $p^{r+1}$ integral of $f(x)$. This gives a Fourier representation of the coefficients in terms of the $p^{k+2}$-integral when the series is bounded $(\mathrm{C}, \mathrm{k})$.

These results are then extended to multiple trigonometric series. A representation for the coefficients in terms of the $C_{k+1} P$-integral is demonstrated if the series is bounded $(T, k)$. Finally, a uniqueness theorem is proved where the summability set is a countable set of $n$-tuples of the form $\left(x_{1,0}, \ldots, x_{n-1,0}, x_{n j}\right)$ for fixed $x_{1,0}, \ldots, x_{n-1,0}$ and $i \geqslant 1$.

Alexis ZINGER, Du choix de la population ayant la plus grande moyenne dans le cas de trois populations normales de variance connues, thèse présentée à l'Université de Montréal, juillet 1957 (professeur J. St. Pierre, directeur).

La présente thèse contient une étude théorique de la distribution non centrale de la différence entre la plus grande et la deuxième plus grande moyenne échantillonnale, lorsque le nombre de populations normales est égal à trois.

Deux genres de problèmes peuvent être résolus à l'aide de cette distribution. Le premier consiste à choisir la population normale ayant la plus grande moyenne, une probabilité de fausse décision étant donnée à l'avance. Le deuxième concerne la planification des expériences. Le nombre d'observations requises pour déceler la population ayant la plus grande moyenne est déterminé en fonction d'un parametre de non centralité donné à l'avance. Ce nombre dépend de la probabilité d'un bon choix de la population en question, ainsi que la probabilité d'un mauvais choix. Dans ce dernier cas une procédure optimum (qui minimise l'espérance mathématique de la dimension échantillonnale) est proposée. 